\title{
Impact of Male Migration on Level of Mobility of Women in Rural Society
}

\author{
Archana Kumari, Meera Singh and Satya Prakash* \\ Department of Home Science Extension and Communication Management, \\ DRPCAU, Pusa, Samastipur, Bihar-848125, India \\ *Corresponding author
}

\begin{tabular}{|c|c|}
\hline & A B S T R A C T \\
\hline $\begin{array}{l}\text { Ke y w o r d s } \\
\text { Migration, } \\
\text { Destination, } \\
\text { Mobility }\end{array}$ & $\begin{array}{l}\text { Migration is the flow of people over shorter or longer distances from place of their origin } \\
\text { to a destination either for temporary or permanent settlement. The study was undertaken in } \\
\text { two blocks of Samastipur districts of Bihar state namely Pusa and Kalyanpur with } 30 \\
\text { migrants family women and } 30 \text { non-migrants family women. It accomplished a total of } \\
\text { sixty women as respondents to know the impact of male migration on level of mobility of }\end{array}$ \\
\hline Article Info & alone outside of home to carry out various activities such as shopping (50\%), health centre \\
\hline $\begin{array}{l}\text { Accepted: } \\
\text { 04 March } 2019 \\
\text { Available Online: } \\
10 \text { April } 2019\end{array}$ & $\begin{array}{l}(33.33 \%) \text { and children's school functions }(26.66 \%) \text {. While in non-migrants family only } \\
(13.33 \%) \text { respondents had gone to market alone. Level of mobility of migrants family } \\
\text { respondents was negatively affected by caste, number of children and family size. While } \\
\text { family income, family occupation and social participation were positively affected the } \\
\text { level of mobility of non-migrants family respondents. Therefore, a positive impact of the }\end{array}$ \\
\hline
\end{tabular}

\section{Introduction}

Bihar is second on the list of states from where most migrant labourers go to other countries. The incidence of migration is higher for the backward districts of North Bihar, in comparison with the better off districts of south Bihar. The main factors contributing to the migration of people from their place to the another place of destination located within and outside states, is expectation of higher income and better prospects of employment which ultimately determine the quality of life Laruelle (2007) observed that due to migration, women gain more authority in household management.
They have to perform housekeeping, take care of children, and work to earn additional income. Mendola and Carletto (2009) reported that having a migrant abroad decreased paid female labour supply, but increased unpaid work. But women with male migration experience were more likely to engaged in self-employment and to a lesser degree unpaid work. So over time, male migration influences women's employment status and income-earning capacity which may lead to increased bargaining power and empowerment. Very few studies have been done on impact of male migration level of mobility of women in rural society. Keeping in view of all above facts, the present study is 
undertaken with the specific objectives to study the impact of male migration on level of mobility of women in rural society.

\section{Materials and Methods}

The study was undertaken in two blocks of Samastipur district of Bihar namely Pusa and Kalyanpur. From each of the blocks two villages were randomly selected. From each block fifteen migrants and fifteen non migrants family women were selected randomly for the study.

It accomplished a total of sixty women as respondents. Data were collected from the selected respondents by using interview schedules developed for study.

\section{Results and Discussion}

The table- 1 reveals that the mobility of migrants and non-migrants family respondents. From the table it has been seen that respondents had gone alone outside of home for activities such as market for shopping (50\%), health center $(33.33 \%)$ and children's school functions $(26.66 \%)$. Whereas cent per cent respondents had visited marriage ceremony or puja accompanied with family members and 90 per cent respondents had not permission for gone to cinema.

Table.1 Distribution of percentage on the basis of level of mobility of women

\begin{tabular}{|c|c|c|c|c|c|c|c|}
\hline \multirow[t]{2}{*}{ Sl. No. } & \multirow[t]{2}{*}{ Type of activities } & \multicolumn{3}{|c|}{ Migrants family $(n=30)$} & \multicolumn{3}{|c|}{ Non-migrants family $(n=30)$} \\
\hline & & Go alone & $\begin{array}{l}\text { Accompanied } \\
\text { with family } \\
\text { members }\end{array}$ & $\begin{array}{l}\text { Not } \\
\text { allowed }\end{array}$ & $\begin{array}{l}\text { Go } \\
\text { alone }\end{array}$ & $\begin{array}{l}\text { Accompanied } \\
\text { with family } \\
\text { members }\end{array}$ & $\begin{array}{l}\text { Not } \\
\text { allowed }\end{array}$ \\
\hline 1. & Market for shopping & $\begin{array}{l}15 \\
(50)\end{array}$ & $\begin{array}{l}13 \\
(43.33)\end{array}$ & $\begin{array}{l}2 \\
(6.66)\end{array}$ & $\begin{array}{l}4 \\
(13.33)\end{array}$ & $\begin{array}{l}18 \\
(60)\end{array}$ & $\begin{array}{l}8 \\
(26.66)\end{array}$ \\
\hline 2. & Bank & $\begin{array}{l}1 \\
(13.33)\end{array}$ & $\begin{array}{l}13 \\
(43.33)\end{array}$ & $\begin{array}{l}16 \\
(53.33)\end{array}$ & $\begin{array}{l}2 \\
(6.66)\end{array}$ & $\begin{array}{l}14 \\
(46.66)\end{array}$ & $\begin{array}{l}14 \\
(46.66)\end{array}$ \\
\hline 3. & Block office/NGO & $\begin{array}{l}2 \\
(6.66)\end{array}$ & $\begin{array}{l}21 \\
(70)\end{array}$ & $\begin{array}{l}7 \\
(23.33)\end{array}$ & $\begin{array}{l}1 \\
(3.33)\end{array}$ & $\begin{array}{l}17 \\
(56.66)\end{array}$ & $\begin{array}{l}12 \\
(40)\end{array}$ \\
\hline 4. & Cinema & - & $\begin{array}{l}3 \\
(10)\end{array}$ & $\begin{array}{l}27 \\
(90)\end{array}$ & - & $\begin{array}{l}7 \\
(23.33)\end{array}$ & $\begin{array}{l}23 \\
(76.66)\end{array}$ \\
\hline 5. & Outside village & $\begin{array}{l}3 \\
(10)\end{array}$ & $\begin{array}{l}27 \\
(90)\end{array}$ & - & - & $\begin{array}{l}14 \\
(46.66)\end{array}$ & $\begin{array}{l}16 \\
(53.33)\end{array}$ \\
\hline 6. & $\begin{array}{l}\text { Meet } \\
\text { friends/relatives }\end{array}$ & $\begin{array}{l}1 \\
(3.33)\end{array}$ & $\begin{array}{l}29 \\
(96.66)\end{array}$ & - & $\begin{array}{l}3 \\
(10)\end{array}$ & $\begin{array}{l}24 \\
(80)\end{array}$ & $\begin{array}{l}5 \\
(16.66)\end{array}$ \\
\hline 7. & $\begin{array}{l}\text { Visiting to Participation } \\
\text { in community activities }\end{array}$ & $\begin{array}{l}3 \\
(10)\end{array}$ & $\begin{array}{l}21 \\
(70)\end{array}$ & $\begin{array}{l}6 \\
(20)\end{array}$ & - & $\begin{array}{l}17 \\
(56.66)\end{array}$ & $\begin{array}{l}10 \\
(33.33)\end{array}$ \\
\hline 8. & $\begin{array}{lr}\text { Visiting marriage } \\
\text { ceremony/puja/ } \\
\text { occasion /festivals }\end{array}$ & - & $\begin{array}{l}30 \\
(100)\end{array}$ & - & - & $\begin{array}{l}29 \\
(96.66)\end{array}$ & $\begin{array}{l}1 \\
(3.33)\end{array}$ \\
\hline 9. & Health centre & $\begin{array}{l}10 \\
(33.33)\end{array}$ & $\begin{array}{l}20 \\
(66.66)\end{array}$ & - & - & $\begin{array}{l}27 \\
(90)\end{array}$ & $\begin{array}{l}3 \\
(10)\end{array}$ \\
\hline 10. & $\begin{array}{l}\text { Attending } \\
\text { pilgrim/religious place }\end{array}$ & $5(16.66)$ & $25(83.33)$ & -- & - & $\begin{array}{l}24 \\
(80)\end{array}$ & $\begin{array}{l}6 \\
(20)\end{array}$ \\
\hline 11. & $\begin{array}{l}\text { Going to children's } \\
\text { school function }\end{array}$ & $\begin{array}{l}8 \\
(26.66)\end{array}$ & $\begin{array}{l}13 \\
(43.33)\end{array}$ & $\begin{array}{l}9 \\
(30)\end{array}$ & $\begin{array}{l}1 \\
(3.33)\end{array}$ & $\begin{array}{l}9 \\
(30)\end{array}$ & $\begin{array}{l}20 \\
(66.66)\end{array}$ \\
\hline & Total & $\begin{array}{l}4.36 \\
(14.54)\end{array}$ & $\begin{array}{l}19.54 \\
(65.15)\end{array}$ & $\begin{array}{l}6.09 \\
(20.30)\end{array}$ & $\begin{array}{l}1 \\
(3.33)\end{array}$ & $\begin{array}{l}18.18 \\
(60.60)\end{array}$ & $\begin{array}{l}10.72 \\
(35.75)\end{array}$ \\
\hline
\end{tabular}

* Figures in parentheses indicates percentage 
Table.2 Relationship of socio-economic variables with level of mobility of women

\begin{tabular}{|c|l|c|c|}
\hline \multirow{2}{*}{ SI. No. } & \multicolumn{1}{|c|}{ Independent variables } & \multicolumn{2}{|c|}{ Value of 'r' } \\
\cline { 3 - 4 } & & \multicolumn{2}{|c|}{ Level of mobility } \\
\cline { 3 - 4 } & & $\begin{array}{c}\text { Migrants family } \\
\left(\boldsymbol{Y}_{\mathbf{1}} \mathbf{A}\right)\end{array}$ & $\begin{array}{c}\text { Non-migrants family } \\
\left(\mathbf{Y}_{\mathbf{1}} \mathbf{B}\right)\end{array}$ \\
\hline $\mathbf{1 .}$ & Age $\left(\mathrm{X}_{1}\right)$ & -.168 & .191 \\
\hline $\mathbf{2 .}$ & Caste $\left(\mathrm{X}_{2}\right)$ & $-.407^{*}$ & .212 \\
\hline $\mathbf{3 .}$ & Education $\left(\mathrm{X}_{3}\right)$ & .345 & .296 \\
\hline $\mathbf{4 .}$ & Land holding $\left(\mathrm{X}_{4}\right)$ & -.009 & .083 \\
\hline $\mathbf{5 .}$ & Family type $\left(\mathrm{X}_{5}\right)$ & -.350 & -.217 \\
\hline $\mathbf{6 .}$ & Family size $\left(\mathrm{X}_{6}\right)$ & $-.582^{* *}$ & -.147 \\
\hline $\mathbf{7 .}$ & No. of children $\left(\mathrm{X}_{7}\right)$ & $-.368^{*}$ & .088 \\
\hline $\mathbf{8 .}$ & Family income $\left(\mathrm{X}_{8}\right)$ & .115 & $.382^{*}$ \\
\hline $\mathbf{9 .}$ & Family occupation $\left(\mathrm{X}_{9}\right)$ & .081 & $.409^{*}$ \\
\hline $\mathbf{1 0 .}$ & Social participation $\left(\mathrm{X}_{10}\right)$ & .222 & $.444^{*}$ \\
\hline $\mathbf{1 1 .}$ & Income of migrants $\left(\mathrm{X}_{11}\right)$ & -.053 & - \\
\hline $\mathbf{1 2}$ & Nature of Employment $\left(\mathrm{X}_{12}\right)$ & -.127 & - \\
\hline $\mathbf{1 3 .}$ & Frequency of communication $\left(\mathrm{X}_{13}\right)$ & -.023 & - \\
\hline $\mathbf{1 4}$. & Causes of migration $\left(\mathrm{X}_{14}\right)$ & .166 & - \\
\hline *Significant at 5\% level of probability & & \\
\hline ** Significant at $1 \%$ level of probability & & \\
\hline
\end{tabular}

In case of non-migrants family majority $(96.66 \%)$ of respondents had visited marriage ceremony/other occasion/festivals accompanied with family members. More than $(70 \%)$ respondents had not allowed for gone to cinema and only (13.33\%) respondents had gone to market alone.

The relation between independent variables and level of mobility of rural women is presented in Table 2 . The level of mobility of migrant's family respondents was significantly and negatively associated with caste, family size and number of children. All other variables were found non-significant. These signified that with the increase in the caste, family size and number of children, the women physical mobility decreases significantly. The level of mobility of nonmigrant's family respondents was significantly and positively associated with family income, family occupation and social participation. All other variables were nonsignificant. The significant variables implied that these variables played significant roles towards the dependent variable.

In conclusion, the findings of the study provide relevant information related with selected migrants and non-migrants family respondents of their level of mobility. The result reveals that the migrants family women had gone outside of home for different activities more than non-migrants family women. The relation between independent variables and level of mobility of migrants family respondents signified that with the increase in the caste, family size and number of children, the women physical mobility decreases significantly. The level of mobility of non-migrant's family respondents was significantly and positively associated with family income, family occupation and social participation. 


\section{References}

Laruelle, M. (2007). Central Asian Labor Migrants in Russia: The" Diasporization" of the Central Asian States In China \& Eurasia Forum
Quarterly. 5(3).

Mendola, M. and Carletto, C. (2009). International migration and gender differentials in the home labor market: Evidence from Albania.

\section{How to cite this article:}

Archana Kumari, Meera Singh and Satya Prakash. 2019. Impact of Male Migration on Level of Mobility of Women in Rural Society. Int.J.Curr.Microbiol.App.Sci. 8(04): 59-62.

doi: https://doi.org/10.20546/ijcmas.2019.804.007 